\section{EMBRYRIDDLE}

Aeronautical University

SCHOLARLY COMMONS
Journal of Aviation/Aerospace

Education \& Research

Volume 27

Number 2 JAAER 2018

Article 3

2018

\title{
Meeting Real World Demands of the Global Economy: An Employer's Perspective
}

\author{
Doreen McGunagle \\ Embry-Riddle Aeronautical University, doreen_mcgunagle@erau.edu
}

Laura Zizka

Ecole hôtelière de Lausanne, HES-SO, University of Applied Sciences Western Switzerland, laura.zizka@ehl.ch

Follow this and additional works at: https://commons.erau.edu/jaaer

Part of the Aerospace Engineering Commons, Computer Sciences Commons, Higher Education Commons, Mathematics Commons, and the Other Physical Sciences and Mathematics Commons

\section{Scholarly Commons Citation}

McGunagle, D., \& Zizka, L. (2018). Meeting Real World Demands of the Global Economy: An Employer's Perspective. Journal of Aviation/Aerospace Education \& Research, 27(2). https://doi.org/10.15394/ jaaer.2018.1738

This Article is brought to you for free and open access by the Journals at Scholarly Commons. It has been accepted for inclusion in Journal of Aviation/Aerospace Education \& Research by an authorized administrator of Scholarly Commons. For more information, please contact commons@erau.edu. 


\section{Introduction}

Education and adequate training are prerequisites for success in the workplace. While academic programs prepare students theoretically for the workplace, many programs are still lacking in the real-world skills that the workplace requires. Graduates are missing the teaching/learning employability skills that are "essential to business competitiveness, but also for prosperity and fairness" (Maxwell, Scott, Macfarlane, \& Williamson, 2010, p. 1). This is especially evident in STEM (Science, Technology, Engineering, and Math) education which has a fundamental role of advancing technology, medicine, sustainability, agriculture, national security, economy, and society (Egarievwe, 2015). STEM programs prepare the next generation of scientists, tech experts, engineers, and mathematicians to meet $21^{\text {st }}$ century, real-world demands in a global economy. These programs, however, are falling short; young STEM graduates lack many of the hard and soft skills that employers require (Appleby, Roberts, Barnes, Qualter, \& Tariq, 2012; Blom \& Saeki, 2012; Dyke-Ford \& Teare, 2006; Hartmann \& Jahren, 2015; Maxwell et al., 2010).

Much money is invested in STEM education, $\$ 40$ billion in the U.S. alone (Charette, n.d.), as STEM learning is linked to national and global economies (Abdelhak, Mohammed, Mohammed, Khalid, \& Abderrahim, 2015) and is considered crucial to future economic success. Economic experts are concerned that a STEM shortage could threaten the U.S. economy (Charrette, n.d.), as only 25\% of the 15 million Americans with STEM degrees work in STEM jobs (Millar, 2014). Although STEM students earn more, are in demand, and are valued across the labor market, many students leave their universities with few ideas about what a real job entails or how to build a career (Hooley, Hutchinson, \& Neary, 2012). Thus, creating an environment that encourages successful partnerships between STEM education and STEM 
employers and accommodates innovation in STEM-related positions is necessary for guaranteeing future economic prosperity in a competitive global economy (Panizzon, Corrigan, Forgasz, \& Hopkins, 2015; Prinsley \& Baranyai, 2015b). This paper aims to establish ways to bridge the gap between STEM education and the STEM workplace.

While previous studies analyzed the hard and soft skill requirements for STEM students' success in the workplace—-such as written, oral presentations, interpersonal communication; team players' proactive, problem solving, decision making ability (Appleby et al., 2012; Hartmann \& Jahren, 2015; Maxwell et al., 2010; McGunagle, 2016) — this study will apply these skills to STEM students in the Airline, Aerospace and Defense (A\&D) workplace and design a model of job skills that will ensure success of the new STEM workforce. Universities could adopt this model to design more effective STEM programs that will prepare future leaders in innovation, productivity, and social change to work within a global economy. At present, there is a lack of information on the necessary skills for workplace success that is specific to A\&D STEM graduates. This paper attempts to fill that gap by offering a model of the skills required of STEM graduates for successful integration into the A\&D workplaces.

The purpose of this study was to explore the employer's perspective on the skills that influence the success of college graduates. The employer perspective was used to construct a framework for understanding the skills that affect new college graduates' success. This study used a purposeful sampling strategy of the $\mathrm{A} \& \mathrm{D}$ and related industries. The study provides a framework for meeting real-world demands and presents a model that will identify key factors in the terms of skills required for the college graduates to succeed in their new positions. The study addresses the following research questions: 
Q1: What are the key work skills that will improve alignment between employers' requirements and STEM programs?

Q2: How do employers rank the importance of job performance skills of new employees?

Results from the study will provide A\&D colleges with a better understanding of any gaps in aligning the work skills they teach with an employer's expectations. By ensuring students are graduating with those skills, A\&D colleges will contribute to the industry by providing a better, more skilled workforce.

\section{Literature Review}

Previous research has identified the mismatch, or gap, between the skills attained in higher education and the transferable skills that are necessary for the workplace (Abdelhak et al., 2015; Appleby et al., 2012; Barnett, 2012; Charette, n.d.; Egarievwe, 2015; Prinsley \& Baranyai, 2015a; Rus, Yasin, Yunus, Rahim, \& Ismail, 2015). In short, STEM employees lack practical experience, general workplace experience, or required business knowledge (Prinsley \& Baranyai, 2015a). While they have academic knowledge, young STEM employees are criticized for their lack of interpersonal and transferable skills necessary in the business environment. STEM graduates must be able to work in their discipline or area of expertise while making connections with other disciplines (Egarievwe, 2015; Madden et al., 2013) and applying their skills to various contexts (Abdelhak et al., 2015). They need to be responsive, proactive, adaptable, and creative (Abdelhak et al., 2015; Prinsley \& Baranyai, 2015a) to produce competitive, innovative solutions to real business problems. In short, employers seek employees who have life skills and life experiences beyond their academic knowledge (Appleby et al., 2012) and can apply this experience and theoretical knowledge in the workplace. 
Of the skills new STEM graduates are lacking, communication is listed as the most important one (Appleby et al., 2012; Maxwell et al., 2010), followed by leadership skills (Hartmann \& Jahren, 2015; Maxwell et al., 2010), problem-solving skills (Blom \& Saeki, 2012; Dyke-Ford \& Teare, 2006; Maxwell et al., 2010), and, finally, team-working skills (Appleby et al., 2012; Hartmann \& Jahren, 2015; Maxwell et al., 2010). Young STEM employees' gaps lie in the higher-order thinking skills, such as analyzing, evaluating, creating (Barnett, 2012; Blom \& Saeki, 2012; Charette, n.d.; Maxwell et al., 2010), and effectively communicating their findings to different stakeholders, including colleagues, clients, or management (Millar, 2014). For Dyke-Ford and Teare (2006), 'their success is as dependent on their ability to communicate as it is on their technical skills' (p. 5); otherwise, their work may go unnoticed or fall short of the expectations of the greater global community.

While young STEM graduates are expected to enter the workplace with higher-level communication skills, employers are prepared to teach skills such as leadership, strategy, and decision-making on the job (Maxwell et al., 2010). Higher-level communication skills include communication at different levels of the organizational structure using different channels and respecting purpose, audience, and medium (Barnett, 2012; Dyke-Ford \& Teare, 2006; Maxwell et al., 2010). This is because data cannot simply be amassed; rather, it must be interpreted and repackaged (Dyke-Ford \& Teare, 2006) for internal and external audiences with varying levels of expertise in and comprehension of the discipline (Appleby et al., 2012; Maxwell et al., 2010). It is necessary to change existing perceptions of communication as simply a one-way presentation of facts to a two-way dialogue that depends on interpersonal skills (Appleby et al., 2012; Barnett, 2012; Maxwell et al., 2010) and behavioral cues. 
Through effective communication, young STEM graduates are expected to engage with their workplace colleagues (internally), but also externally, with clients and external stakeholders. These opportunities for engagement can come from the application of authentic, real-world projects, which foster creativity and innovative cognitive skills in young STEM graduates through cross-disciplinary problem identification and solving skills (Dyke-Ford \& Teare, 2006; Egarievwe, 2015; Madden et al., 2013). Successful STEM employees who have learned to combine their competencies, transfer their skills from one task to the next, from one job to another (Maxwell et al., 2010), and effectively communicate to all stakeholders are strong candidates for leadership positions in the global workplace. These potential leaders demonstrate early on higher-level skills of learning from mistakes, reflective thinking, social responsibility, and lifelong learning (Madden et al., 2013). Real life projects which stimulate STEM students to apply what they have learned, lead a team, devise new and exciting solutions, and communicate it all to the various stakeholders are key to the success of STEM programs.

Learning is an active, reflective process, and young STEM graduates are on a learning journey (Abdelhak et al., 2015; Blom \& Saeki, 2012; Egarievwe, 2015; Madden et al., 2013; Maxwell et al., 2010; Rus et al., 2015). Higher education STEM programs offer the theoretical knowledge and industry-related competences, which should prepare STEM graduates for the work environment. These programs offer opportunities for STEM students to learn by doing (Millar, 2014), to learn from experience (Rus \& Yasin, 2015), to learn how to learn (Appleby et al., 2012). Employers expect these STEM graduates to continue learning throughout their career, beyond the 'threshold concept' of learning only the key concepts to master their subject area (Appleby et al., 2012) and become lifelong learners who are capable and willing to learn new skills in the workplace. 
Previous literature identified that the number one skill wanted by employers was communication skills, demonstrating effective listening and oral communication as one of the most important competencies looked for when hiring (Carnevale, Smith, \& Strohl, 2013; Finch, Hamilton, Baldwin, \& Zehner, 2013; Carnevale et al., 2013; Pefanis Schlee \& Harich, 2010; Chamorro-Premuzic, Arteche, Bremmer, Greven, \& Furnham, 2010). The second highest category was adaptability that demonstrate problem solving and creative thinking (Carnevale et al., 2013; Finch et al., 2013; Pefanis Schlee \& Harich, 2010; Wellman, 2010). The third most important category was applied skills completed through internship and cooperative education (Carnevale et al., 2013; Finch et al., 2013; Gault, Leach, \& Duey, 2010). The literature demonstrates a strong correlation with the top three workforce skill categories with employability upon graduation but do not address the transition to the workforce.

Due to the complexity of projects, further research found that soft skills were extremely important in the aerospace industry jobs (McGunagle, 2016; Azim et al., 2010). McGunagle (2016) analyzed the current job listings from 17 of the top Aerospace \& Defense Industry (A \& D) Organizations from the Deloitte Touche Tohmatsu Limited (DTTL) 2014 Global A \& D sector financial performance study. The A \& D companies in Table 1 represent $53 \%$ of the industry. 
Table 1

Website Sources for Data Collection

\begin{tabular}{lll} 
Rank & Company & Revenues (U.S. \$ MILLIONS) \\
\hline & & \\
1 & The Boeing Company & 86,623 \\
2 & Airbus Group & 78,692 \\
3 & Lockheed Martin & 45,358 \\
5 & General Dynamics & 31,218 \\
6 & BAE Systems & 26,380 \\
8 & Rolls-Royce & 24,255 \\
9 & Raytheon & 23,706 \\
14 & L-3 Communication & 12,629 \\
15 & Textron & 12,104 \\
16 & Bombardier Aerospace & 9,385 \\
17 & Precision Castparts & 8,378 \\
& Total Revenues & 358,728
\end{tabular}

\section{Methodology}

Participants were from five organizations that met the criteria of hiring of STEM students in the past 12 months. The hiring managers from these organizations had hired 432 students. The participants represented $30 \%$ of the 17 organizations in Table 1. Participants who had positions open and did not hire STEM students were excluded from the research. The hiring managers were interviewed to discuss the employer's perception of soft skills deemed important for STEM positions. During the interviews with the employers, they were asked to rate the job skills rated by importance to the STEM positions, discuss the colleges that they had recruited their college graduates, the number of college graduates they had hired, and discuss any other related skills that were not covered. The soft skills were ranked by importance to the positions by the hiring mangers utilizing a Likert type scoring system of 1-5, with 5 being the highest. A transcript of the interview was provided to the participant for validation of the data collected. 


\section{Results}

In research Question 1: What are the key work skills that will improve alignment between employer's requirements and STEM programs?

The five interviews discussed the hiring of 432 STEM students. The hiring managers expect that STEM students that are hired should have the soft skills in Table 2. During interviews with the candidates, employers ask several questions that relate to these skills to determine the qualifications of the candidate. Table 2 was deemed as essential skills that were important and their success in the position.

Table 2

Soft Skills

Written, Oral Presentations, Interpersonal Communication

Team Player

Proactive, Problem Solving, Decision Making Ability

Ability to Synthesize, Gather Data

Leadership

Self-Motivated, High Self-Confidence

Customer Focus

Negotiation Skills

Adaptability

Source: McGunagle, 2016

The skills listed on Table 2 demonstrate that a model for higher education programs that prepare STEM students for their first employment positions must be created and implemented to ensure graduates can indeed meet the real-world demands and challenges that they are expected to meet.

In research Question 2: How do employers rank the importance of job performance skills of new employees? 
Table 3 provides a detailed list of the average ratings from the interviews. In response to research Question 2, Table 3 shows the job skills which employers rated (from 1-5) as the most important for the workplace. These 16 job skills had been identified by A\&D employers in an earlier study on STEM students and meeting real world demands (McGunagle, 2016). While the list is not exhaustive, it does give an overview of the most pertinent job skills for STEM students that employers deem most important to their success in a position.

Table 3

Survey Results

\begin{tabular}{|c|c|c|c|c|}
\hline Soft Skill & Mean & SD & Min & Max \\
\hline Team Player & 4.4 & .5477 & 4 & 5 \\
\hline Negotiation & 2.2 & .4472 & 2 & 3 \\
\hline Verbal Communication & 3.8 & .4472 & 3 & 4 \\
\hline Written Communication & 3.8 & .4472 & 3 & 4 \\
\hline Oral Communication & 3.2 & 1.095 & 2 & 5 \\
\hline Problem Solving & 4.8 & .4472 & 4 & 5 \\
\hline Decision Making & 3.6 & .8944 & 3 & 5 \\
\hline Assertive & 2.8 & .4472 & 2 & 3 \\
\hline Proactive & 4.2 & .4472 & 4 & 5 \\
\hline Self-Motivated & 4 & .7071 & 3 & 5 \\
\hline Self-Confidence & 3.2 & .4472 & 3 & 4 \\
\hline Synthesize & 3.8 & .4472 & 3 & 4 \\
\hline Gathering Data & 4.6 & .5477 & 4 & 5 \\
\hline Leadership & 3.6 & .8944 & 3 & 5 \\
\hline Customer Focus & 4 & .7071 & 3 & 5 \\
\hline Adaptability & 4.8 & .4472 & 4 & 5 \\
\hline
\end{tabular}

Two additional skills which were identified during the interviews, will be added to future studies. The two skills disclosed during the interviews were time management and active listening skills. Further comments that were supplied by the companies included the importance of real-life applications during their classes. In this way, the culture shock between school and the workplace could be avoided. In some cases, STEM students were summarized as "being 
book smart but not exposed to common sense." This presents a real challenge to higher educational programs that seek to produce the best and brightest STEM students for the future success of society but are currently lacking in preparing them for the present, short-term reality of the day-to-day workplace.

\section{Conclusions and Implications}

This study examined STEM students and their ability to adapt in the workplace. In an earlier study (McGunagle, 2016), meeting real-world demands were analyzed through the hard and soft skill requirements for the STEM based jobs that will ensure the future success of a new job applicant in $\mathrm{A} \& \mathrm{D}$ organizations. It was found that communication skills were the most sought after skill for young graduates, followed by being a team player, and problem solving. This study attempted to further the discussion on the real needs of STEM students to succeed in the workplace. While this study focused on employers and their expectations of STEM students being fully functional immediately upon employment, a future study could focus on STEM student curriculum and the areas which need improvement, namely the problem solving, adaptability, ability to gather (and communicate) data, and teamwork.

Today's workplaces are evolving with an emphasis on continuous professional development and real-life problem solving, leading to deeper employee engagement (Madden et al., 2013; Maxwell et al., 2010). Employers spend billions annually on training and education, but only a fraction of that is spent within the higher education sector (Maxwell et al., 2010). To prepare potential STEM leaders and fully profit from their investment in young STEM graduates, employers can be proactive. Some actions include mentoring, internships, and co-creation of curriculum for higher education. In mentoring programs, employers create partnerships with higher education institutions (Baxter \& Waldock, 2012) to help STEM students hone career- 
building behaviors, work in teams, see the big picture, and address social expectations, boundaries, and limits to adjust to a new job/environment (Veenstra, 2014). STEM students who have had a positive experience with a mentor are more likely to become mentors themselves (Baxter \& Waldock, 2012). This propagates the best practices of addressing and meeting real world needs from one generation of graduates to the next.

Mentoring may be a stand-alone commitment by an employer to a STEM student, or it may be part of a larger engagement through an official internship contract between employer, the school, and the STEM student. While " $81 \%$ of hiring managers believe that college students should have finished a formal internship before graduating and entering the workplace" (Charette, n.d.) to gain a reality check of what the workplace really is (Barnett, 2012; Maxwell et al., 2010) and to bridge the gap between school and work, many STEM companies do not offer them. For employers, internships can be expensive undertakings for legal (Maertz, Stoeberl, \& Marks, 2014), administrative (Prinsley \& Baranyai, 2015b), or human capital reasons (Prinsley \& Baranyai, 2015b). However, employers can benefit from internships as well by profiting from the "try-out" of extra labor capacity, a "low cost, low-risk opportunity for employers to evaluate interns as potential employees, even as they contribute productive work" (Maertz et al., 2014, p. 130). In return, STEM interns gain job-related skills and knowledge as they apply the theory they have learned in STEM programs to real-life situations (Barnett, 2012) and social skills such as networking, communication, and interpersonal skills. For higher education, internships create on-going relationships with companies, which increases corporate or community visibility of the school (Maertz et al., 2014) and helps students build skills and competencies for every transition in their future lives, not just the first job (Hooley et al., 2012). Thus, the importance of internships extends beyond the short-term goal of getting a good first job. 
Employers can take a greater role in education by co-creating curriculum with higher education institutions for STEM students, which is beneficial for both sides. Instructors could engage in professional reflection with STEM industries (Barnett, 2012; Madden et al., 2013) to teach creative thinking strategies and metacognitive thinking to produce "creative scientists who can develop innovative solutions to serious global problems" (Madden et al., 2013, p. 546). Employers could provide real-world contexts for instructors, which encourages engagement between the three stakeholders: the institution, the students, and the employers (Hooley et al., 2012). The importance of dialogue between STEM industries and higher education institutions is the key to improving higher education courses (Maxwell et al., 2010). One way could be to encourage employers to teach at the higher education institutions (Prinsley \& Baranyai, 2015a) or participate in conferences between STEM industry and the institutions of higher learning (Egarievwe, 2015; Veenstra, 2014). Stakeholders, particularly potential employers, who engage early on in the STEM's education, will be more likely to reap the benefits of a STEM workforce that meets their specific needs and expectations.

\section{Limitations and Future Studies}

There were several limitations to this study. First of all, the sampling for the interviews derived from managers in the A\&D industry. A future study could include other industries that rely on STEM students. Secondly, participants were asked to rank the 16 key factors on a Likert scale, but no further ranking was requested. Another study could take the same 16 key factors and analyze them based on specific positions or departments. Further, the 16 key factors could be compared by groups. Thirdly, no STEM students/graduates were included in the sample. A study that focuses on their expectations would be prudent to make strategic decisions of how to implement new skills into STEM university programs. Finally, this study was conducted at one 
moment in time; a future study could trace the needs and expectations as the young graduates evolve in the workplace.

Through these studies, we are one step closer to developing a model of key factors for STEM programs which will improve the alignment between employer's requirements and highwage, high-demand jobs. This study, and those that follow, will help fill the gap on employer's expectations and the necessary skills required to compete in the global economy. There is no question about the necessity of hiring STEM students to find new solutions, creating innovative technology, and shaping the future; rather, the question lies in how they will successfully integrate the workplace and produce collaborative works of genius; this is where the future rests. 


\section{References}

Abdelhak, A., Mohammed, T., Mohammed, R., Khalid, S., \& Abderrahim, T. (2015). Quality management in vocational training: Evaluation of a specialized institution in Ict.

Procedia-Social and Behavioral Sciences, 191, 1928-1933.

https://doi.org/10.1016/j.sbspro.2015.04.261

Appleby, Y., Roberts, S., Barnes, L., Qualter, P., \& Tariq, V. (2012). Who wants to be able to do reference properly and be unemployed? STEM student writing and employer needs. Journal of Learning Development in Higher Education. Retrieved from http://journal.aldinhe.ac.uk/index.php/jldhe/article/view/188

Azim, S., Gale, A., Lawlor-Wright, T., Kirkham, R., Khan, A., \& Alam, M. (2010). The importance of soft skills in complex projects. International Journal of Managing Projects in Business, 3(3), 387-401. Retrieved from https://doi.org/10.1108/17538371011056048

Barnett, K. (2012). Student interns' socially constructed work realities: Narrowing the work expectation-reality gap. Business and Professional Communication Quarterly, 75(3), 271-290. https://doi.org/10.1177/1080569912441360

Baxter, A., \& Waldock, J. (2012). Developing employer engagement in STEM through career mentoring. Sheffield Hallam University.

Blom, A., \& Saeki, H. (2012). Employability and skill sets of newly graduated engineers in India: A study. IUP Journal of Soft Skills, 6(4), 7-50. 
Carnevale, A. P., Smith, N., \& Strohl, J. (2013). Recovery: Job growth and education requirements through 2020. Retrieved from Georgetown University, Georgetown Public Policy Institute, Center on Education and the Workforce website: https://cew.georgetown.edu/report/recovery-job-growth-and-education-requirementsthrough-2020/

Chamorro-Premuzic, T., Arteche, A., Bremner, A. J., Greven, C., \& Furnham, A. (2010). Soft skills in higher education: Importance and improvement ratings as a function of individual differences and academic performance. Educational Psychology: An International Journal of Experimental Educational Psychology, 30(2), 221-241. https://doi.org/10.1080/01443410903560278

Charette, R. N. (n.d.). STEM graduates not workforce ready? Employers should look in the mirror as to why. Retrieved from http://www.advanc-ed.org/source/stem-graduates-notworkforce-ready-employers-should-look-mirror-why

Deloitte Touche Tohmatsu Limited. (2014, July). Global aerospace and defense sector financial performance study. Retrieved from http://gx-mfg-2014aandd-global-financialperformance-study.pdf

Dyke-Ford, J., \& Teare, S. W. (2006). The right answer is communication when capstone engineering courses drive the questions. Journal of STEM Education, 7(3/4), 5-12.

Egarievwe, S. U. (2015). Vertical education enhancement - A model for enhancing STEM education and research. Procedia Social and Behavioral Sciences, 177, 336-344. https://doi.org/10.1016/j.sbspro.2015.02.354 
Finch, D. J., Hamilton, L. K., Baldwin, R., \& Zehner, M. (2013). An exploratory study of factors affecting undergraduate employability. Education + Training, 55(7), 681-704. https://doi.org/10.1108/ET-07-2012-0077

Gault, J., Leach, E., \& Duey, M. (2010). Effects of business internships on job marketability: The employers' perspective. Education + Training, 52(1), 76-88. https://doi.org/10.1108/00400911011017690

Hartmann, B. L., \& Jahren, C. T. (2015). Leadership: Industry needs for entry-level engineering positions. Journal of STEM Education, 16(3), 13-19. Retrieved from https://www.jstem.org/index.php/JSTEM/article/view/1965

Hooley, T., Hutchinson, J., \& Neary, S. (2012). Supporting STEM students into STEM careers: A practical introduction for academics. Retrieved from http://hdl.handle.net/10545/231614

Madden, M. E., Baxter, M., Beauchamp, H., Bouchard, K., Habermas, D., Huff, M., Ladd, B., Pearon, J., \& Plague, G. (2013). Rethinking STEM education: An interdisciplinary STEAM curriculum. Procedia Computer Science, 20, 541-546. https://doi.org/10.1016/j.procs.2013.09.316

Maertz, C. P., Stoeberl, P. A., \& Marks, J. (2014). Building successful internships: Lessons from the research for interns, schools, and employers. Career Development International, 19(1), 123-142. https://doi.org/10.1108/CDI-03-2013-0025

Maxwell, G., Scott, B., Macfarlane, D., \& Williamson, E. (2010). Employers as stakeholders in postgraduate employability skills development. International Journal of Management Education, 8(2), 1-11. https://doi.org/10.3794/ijme.82.267 
McGunagle, D. (2016). Meeting real world demands of the global economy. Journal of Management, 10(3).

Millar, E. (2014). The expectation gap: Students' and universities' roles in preparing for life after grad. Canadian University Report. Retrieved from https://www.theglobeandmail.com/news/national/education/the-expectation-gap-studentsand-universities-roles-in-preparing-for-life-after-grad/article21187004/?page=all

Panizzon, D., Corrigan, D., Forgasz, H., \& Hopkins, S. (2015). Impending STEM shortages in Australia: Beware the 'smoke and mirrors'. Procedia - Social and Behavioral Sciences, 167, 70-74. https://doi.org/10.1016/j.sbspro.2014.12.644

Pefanis Schlee, R., \& Harich, K. R. (2010). Knowledge and skill requirements for marketing jobs in the 21st century. Journal of Marketing Education, 32(3), 341-352. https://doi.org/10.1177/0273475310380881

Prinsley, R., \& Baranyai, K. (2015a). STEM skills in the workforce: What do employers want? Office of the Chief Scientist, (9), 1-4.

Prinsley, R., \& Baranyai, K. (2015b). STEM-trained and job ready. Office of the Chief Scientist, (12), 1-4.

Rus, R. C., \& Yasin, R. M. (2015). Cultivating learning: A grounded theory of skills acquisition for vocation in modern apprenticeships. Procedia - Social and Behavioral Sciences, 174, 275-282. doi:10.1016/j.spspro.2015.01.658

Rus, R. C., Yasin, R. M., Yunus, F. A. N., Rahim, M. B., \& Ismail, I. M. (2015). Skilling for job: A grounded theory of vocational training at industrial training institutes of Malaysia. Procedia - Social and Behavioral Sciences, 204, 198-205. doi:10.1016/j.spbspro.2015.08.139 
Veenstra, C. (2014). The collaborative role of industry in supporting STEM education. The Journal for Quality and Participation. Retrieved from https://static1.squarespace.com/static/51fafa0ee4b0d906af53ce83/t/54510ce0e4b079609a 8875fe/1414597856268/educators-world-the-collaborative-role-of-industry-insupporting-stem-education.pdf

Wellman, N. (2010). The employability attributes required of new marketing graduates. Marketing Intelligence \& Planning, 28(7), 908-930. https://doi.org/10.1108/02634501011086490 